\title{
Developing Snake Ladder Game Learning Media to Increase Students' Interest and Learning Outcomes on Social Studies in Elementary School
}

\section{Ahmad Syawaluddin', Sidrah Afriani Rachman', and Khaerunnisa'}

\begin{abstract}
Background and Objective. One of the challenges that social studies presents to teachers in class is the lack of students' interest in the material. This study aims to develop snakes and ladders learning media for use in the subject of social studies in elementary school.

Method. The research design used is the Four-D Research and Development (R\&D) model by Thiagarajan (Santoso \& Albaniah). The criteria used as a reference for the effectiveness of the learning media are students' participation, interest, and learning outcomes, whereas for the practicality, the criteria are the implementation and teachers' ability to use the learning media. The research employed descriptive statistics analysis and inductive-deductive flow analysis.

Results. The results show that the snakes and ladders learning media on social studies appear to be valid and practical, and can effectively improve elementary school students' interest and learning outcomes. The learning media is considered valid based on the experts' validation with average 4.3 (good). The effectiveness of this learning media meets the criteria: (I) student participation in the learning process is high and (2) student learning outcomes meet the minimum learning mastery standard average at 79.04 of the ideal score of 100 and the completeness test of learning outcomes with
\end{abstract}

'Primary School Teacher Education FIP UNM, Indonesia

Corresponding Author:

Ahmad Syawaluddin, Kampus FIP UNM, JI.Tamalate I, Tidung, Makassar, Indonesia

Email: unmsyawal@unm.ac.id 
the probability value of one sample t-test of $0.00<0.05$. The practicality of the learning media is shown through the observation result of the implementation of the media with an average of 4.4 (good), whereas the results of the student interest questionnaire show that of 25 students (92\%) responded that they were happy with the subject matter taught, $80 \%$ of students responded that they were happy with the learning.

Conclusion. The snakes and ladders learning media on social studies can enhance students' interest and learning outcomes in elementary education.

\section{Keywords}

media development, snakes and ladders, social studies

\section{Introduction}

The level of learning interest a person has might affect their learning outcomes. Interest gives more drive to the learning process of students, which is indicated by the increased attention, participation, and student interest; Hidi and Renninger as cited in Swarat et al. (2012) claim interest as "a motivational variable refers to the psychological state of engaging or the predisposition to reengage with particular classes of objects, events, or ideas over time" (p. 517). Research has shown that interest relates to learners' selection of strategies which also predict their learning outcome. Roure et al. (2019) contend that there is a correlation between attention demand and instant enjoyment to students' learning strategies, therefore teachers may enhance students' exploration of the learning task while creating exciting and stimulating activities.

Among the subjects taught in elementary schools, teaching social studies can be quite a challenge for teachers. A study of social studies in Indonesian elementary schools reveals that the learning process tends to be non-contextual, thus students seem to be less interested, less enthusiastic, bored and sleepy when studying the subject (Hicks et al., 2012; Uge, 2019) explains that social studies are within the key social science diciplines of history, geography, economics, government and civics. The purpose of social studies in elementary education is to promote positive behavior of learners in line with the culture, values, customs and traditions that exist in society (Nora, n.d.). This crucial role of social studies for learners requires the learning instructions to be well-prepared otherwise teachers will make the learning meaningless.

Teaching this subject using traditional textbook-based activity can be somewhat dismal and tedious to young learners who are likely to benefit more from experiental learning when dealing with abstract concepts. Games as one of the various experiental learning methods may engage students' emotions and senses which indicate their active involvement in the learning process; (Geroimenko, 2019) asserts that gamebased learning is ideal because it makes students work toward a goal, choosing actions, and experiencing the consequences of their actions.

It is common to hear children dislike social studies and consider it as one of their less favorite subjects at school. Thus, teachers are expected to foster students' interest 
in learning this concept-based subject. They can assist students in building their interest by creating conducive and pleasant learning conditions. This will certainly trigger students' interest in participating in the learning process. One way to provide interesting learning media so that students do not get bored during the learning process is through the development of game-based learning. The media used to facilitate communication in such a learning process are often termed instructional media.

The use of instructional media has an important role in the learning process. Hamalik in Astuti et al. (2019) states that "the use of instructional media in the teaching and learning process can generate new desires and interests, generate motivation and stimulation of learning activities and even bring psychological influences on students" (p. 212). However, Kemp and Dayton in Lindasari et al. (2019) revealed that "the use of instructional media must fulfill three main functions if the media is used in large groups, two of which are the media must be able to increase interest or action and to give instructions" (p. 357). The role of learning media for the purpose of instruction is to engage students cognitively and emotionally. This means that with the use of the learning media, students put efforts into practicing a deeper learning and to be interested in, motivated by, and contented with the learning. The development of game-based learning media might affect students' interest in the learning process.

Snakes and ladders is one of the game-based learning media developed in this study. Snakes and ladders is a traditional game that is usually played by children. The concept of the snakes and ladders game is very simple where the game is played by two or more children using tools such as dice, a picture consisting of a number of squares where there is a picture of snakes and ladders. According to Ibam et al. (2018) the snakes and ladders game is a board game for children played by two or more players. The game board is divided into small boxes, and there are a number of stairs and snakes that connect the boxes. Snakes and ladders is played by using three items, namely dice, pawns and the snakes and ladders boards. However, snakes and ladders game may consist of several elements including game boards, dice, pawns, cards containing questions, science cards, bonus cards, suprise questions, and zonk cards (Meriyati et al., 2019). The dice serves as a determinant of steps every time the pieces move. The pawn is a counter which will be run by each player. In the game, if the players land on a ladder, it means their pawn can go up in accordance with the ladder, and if the players stop at a snake's tail, they must go down to the snake mouth meaning that they will be left behind.

The game may also be called Moksha Patam in Asia or Chutes and Ladders in western countries. Many recent studies have used this game not only in the teaching process but also in the assessment process. Ibam et al. (2018) investigated the teaching of moral and societal rules through Snakes and Ladders and found out that the students' knowledge on these rules improved. Srinivasan (2019) assessed the effectiveness of snakes and ladders on learners' level of knowledge regarding oral health, knowledge, attitude, and behaviour among students with learning difficulties. Due to the educational effectiveness of employing Snakes and Ladders games, this article outlines the development of a snakes and ladders game as learning media in order to enhance students' interest and learning outcomes in primary education. 


\section{Research Method}

This study aims to develop the learning media of a snakes and ladders game to increase students' interest and learning outcomes in the subject of social studies in elementary school. The method used in this research was the research and development (R\&D) method. Research and development of learning media was designed using the Four-D Development Model by Thiagarajan (Santoso \& Albaniah, 2020) which consists of four stages, namely defining, designing, developing, and disseminating. In the defining stage, researchers set and defined the needs in the learning process. They did learners, concept and task analysis, as well as learning objectives specification. In this study, the researchers also conducted a preliminary study by observing the social studies teaching and learning process and interviewing the teachers. The preliminary study revealed that most teachers still use traditional methods in teaching social studies such as lecturing, reading, and group work. In addition, the learning appeared to be monotonous and less interesting to the students. In the designing stage, there are steps to be completed from product planning to final product based on the snakes and ladders game characteristics. In the developing stage, the researchers integrated the content of social studies by developing the cards which consist of questions on the materials. Afterwards, the researchers asked for expert appraisal and did revision before developmental testing.

The location of this study is at Makassar Mappala Elementary School with the subject of the study being the teacher and the fifth grade students attending social studies lessons dealing with the concept of kingdoms and relics of Hindu Buddhist history. This study uses the non-probability purposeful sampling technique because we needed to select participants who fit a certain profile for teacher and student participation. The teacher is willing to colaborate with the researchers for the teaching and learning process and also has background knowledge of the snakes and ladders game. The students are interested in learning with the use of snakes and ladders learning media in the given material. Thus, before conducting the study, researchers held a meeting with the teacher and the headmaster to communicate the objectives of the study. The parents and the caregivers of the students were also informed and asked to sign the consent form. After that, the students and the teacher were invited to complete the assent process. They could withdraw their participation anytime without giving any specific reason to the researchers.

Data collection techniques used in this study were learning media validation sheet, students' and teachers' activity observation sheet, observation of learning media implementation sheet, students' response questionnaire, test of interest and learning outcomes. The learning media validation sheet to be filled by experts who are a senior lecturer in primary school teacher education specializing in media development and an elementary school social studies teacher relates to style and content of the learning media. Style includes the attractiveness, illustration as well as the suitability of physical size of the snakes and ladders board. Content covers the appropriateness of contents and curriculum. 
The observation sheet of students' activity includes their engagement with the learning process and their participation in the use of the snakes and ladders learning media. Meanwhile, the teacher's ability observation sheet covers management of the class including the application of all the learning stages in the lesson plans and the use of snakes and ladders learning media to promote students' learning. The learning media implementation sheet observes the practicality of the learning media when used by the teacher during the classroom instruction. Students' responses are in terms of material, teacher's instruction and their feeling when the teacher uses snakes and ladders learning media to teach social studies. Students' interest and learning outcomes were also measured using a set of questions.

The data analysis technique used in this research is Descriptive Statistics analysis using mean, standard deviation, ideal score, lowest value and highest value. In addition, Inductive-Deductive flow analysis is also used when the research takes place.

\section{Results}

\section{Developing Snakes and Ladders Learning Media With Four-D Development Model}

The development of the snakes and ladders learning media in this study uses the Four-D development model which consists of four stages, namely defining, designing, developing, and disseminating; however in the fourth stage, no further dissemination has yet been carried out.

Defining stage. The front end analysis was to find out the teacher's main problems in teaching social studies by conducting direct interviews and observation. The preliminary study revealed that most teachers still use traditional methods in teaching social studies such as lecturing, reading, and group work. In addition, the learning appeared to be monotonous and less interesting to the students. The researcher analyzed the learners' characteristics, cognitive development, and skills to be considered in the development of this snakes and ladders learning media. At the material analysis stage, the materials and learning objectives were determined to be in accordance with the school curriculum in which the materials cover (1) Hindu kingdoms in Indonesia, (2) Hindu historical relics in Indonesia, (3) Majapahit work and the role of elephants in unifying the archipelago, (4) kingdoms and relics of Buddhism in Indonesia, (5) the Kingdom of Sriwijaya as the center of the Spread of Buddhism in Indonesia, (6) Historical figures in Hinduism, and (7) Historical figures in Buddhism. The learning objectives are for students to be able to: (a) master conceptual knowledge in social studies learning in elementary school and (b) demonstrate their conceptual knowledge of social studies learning in elementary schools.

Designing stage. There are several steps to be completed from product planning based on the snakes and ladders game characteristics. It was decided on a board consisting of five horizontal squares and eight vertical squares which contain the numbers 1 
(start) to 40 (finish). Some of the contents contained in the game are (1) Stairs, (2) Snakes, (3) Historical figures, (4) Historical Relics (in the form of prasasti or temples), and (5) Quiz / questions to support the course of social studies learning. The researchers integrated the content of social studies by developing cards which consist of questions on the materials. Afterwards, the researchers asked for expert appraisal and carried out revision before developmental testing.

Development stage. The development stage was carried out through two steps, namely: (1) expert appraisal followed by revisions, (2) developmental testing of the learning media. The experts assessed the style and the content of the learning media. The result of this validation suggests that the snakes and ladders learning media is good and can be used with little revision.

\section{Implementation of Snakes and Ladders Learning Media}

The learning media test was conducted at SDN Mappala grade 5, which was attended by 25 students, one teacher and two observers with each carrying out specific observation tasks - namely one person observing the activities of students in learning and one person observing the teacher's ability to manage cooperative learning settings by using the snakes and ladders learning media. The trial was held for 4 meetings in accordance with the planned implementation of learning. In the learning process, students are grouped into 6 groups where each group consists of 4 or 5 people. Heterogeneous division of groups is based on previous test scores about social studies learning.

The test results of the learning outcomes were analyzed using the SPSS program's One Sample t-test. Benchmark criteria are at a value of 65 which is the minimum achievement standard (KKM value) of students and the category is in the previous scoring guidelines. As seen in Table 1, the mean score of students' learning outcome in social studies was 79.04 which exceeded the KKM value.

As seen in Table 2, a probability value of $0.00<0.05$ is obtained. Thus, null hypothesis which states that the average learning outcome is less than 65 is rejected. This means that the average grade of elementary school students exceeds 65 points. Based on observations of student activity, it is shown that most students are active in learning; 22 of the 25 students ( $88 \%$ ) are classified in the active student category and only 3 students (12\%) are inactive. Thus it can be concluded that on average students are active in participating in social studies learning with the use of the snakes and ladders learning media. Based on the observation data, the overall implementation of learning is good. This is indicated by the average value of the learning process. The average learning process in the first meeting to the fourth meeting was 4.4 (good).

The results of the questionnaire on students' interest in the learning process and the snakes and ladders learning media were that $92 \%$ of students responding happily to the subject matter being taught, $80 \%$ of students responding happily to the learning model with the snakes and ladders game. In addition, $72 \%$ of students were happy with the way the teacher teaches and $76 \%$ of students were happy with the learning atmosphere in the classroom. $92 \%$ of students expressed interest in participating in social studies 
Table I. Descriptive Statistics Results.

\section{Statistics}

Social Studies Learning Outcome

\begin{tabular}{|c|c|c|}
\hline \multirow[t]{2}{*}{$\mathrm{N}$} & Valid & 25 \\
\hline & Missing & 0 \\
\hline Mean & & 79.04 \\
\hline Std. Error of Mean & & 1.992 \\
\hline Median & & 80.00 \\
\hline Mode & & 80 \\
\hline Std. Deviation & & 9.960 \\
\hline Variance & & 99.207 \\
\hline Range & & 37 \\
\hline Minimum & & 56 \\
\hline Maximum & & 93 \\
\hline Sum & & 1976 \\
\hline
\end{tabular}

Table 2. Inferential Statistics Result.

\begin{tabular}{|c|c|c|c|c|c|c|}
\hline \multicolumn{7}{|c|}{ One-Sample Test } \\
\hline & \multicolumn{6}{|c|}{ Test Value $=65$} \\
\hline & \multirow[b]{2}{*}{$\mathrm{t}$} & \multirow[b]{2}{*}{$d f$} & \multirow[b]{2}{*}{ Sig. (2-tailed) } & \multirow{2}{*}{$\begin{array}{c}\text { Mean } \\
\text { Difference }\end{array}$} & \multicolumn{2}{|c|}{$\begin{array}{l}95 \% \text { Confidence Interva } \\
\text { of the Difference }\end{array}$} \\
\hline & & & & & Lower & Upper \\
\hline HasilBelajar IPS & 7.048 & 24 & .000 & 14.040 & 9.93 & 18.15 \\
\hline
\end{tabular}

learning. In fact, the results for students' interest in the learning process and social studies learning media are very high. Most students agree that learning with snakes and ladders learning media is more fun and easier to understand.

\section{Validity, Practicality, and Effectiveness of Snakes and Ladders Game Learning Media}

The learning media developed by researchers are that of a snakes and ladders game. The initial preparation of the developed learning media is called draft 1 . After being validated by experts, the results obtained an average of 4.3 (good), indicated that the media can be played by students and can be used with little revision. The results for effectiveness can be seen from the results of descriptive and inferential statistics. Students' learning outcomes meet the minimum learning mastery standard average at 
79.04 of the ideal score of 100 and the completeness test of learning outcomes with the probability value of one sample t-test of $0.00<0.05$.

Observations of student activities show that most students are active in learning, 22 (or $80 \%$ ) of 25 students included in the category of active students and only 3 students $(12 \%)$ are not active. The effectiveness test of the learning media developed has been fulfilled. This can be seen from (1) the student learning outcomes test is complete; (2) the activity of students when participating in learning is very high. The practicality of the developed learning media can be measured by the following criteria: (1) the implementation of media and the teacher's ability to manage learning with learning media that are developed in the minimal good category, (2) students have very high interest in the learning process and the learning media.

The results of observations of the implementation of learning showed the implementation of learning took place well with an average of 4.4 , while the results of the students' interest questionnaire showed that out of 25 students involved in the learning process using snakes and ladders learning media $92 \%$ of students responding happily to the subject matter being taught, $80 \%$ of students responded happily to the social learning model of cooperative setting with snakes and ladders learning media. In addition, $72 \%$ of students were happy with the way the teacher teaches and $76 \%$ of students were happy with the learning atmosphere in the classroom. $92 \%$ of students expressed interest in participating in social studies learning. According to $92 \%$ of students, learning with a cooperative setting with the snakes and ladders learning media is more fun and easier to understand. Thus, the results show that students' interest in the learning process and social studies learning media are very high.

\section{Discussion}

This study describes the development of snakes and ladders learning media to increase elementary school learners' interest and learning outcomes in social studies. The product produced was a package of snakes and ladders learning media which had been assessed for its validity, effectiveness, and practicality. The result of expert appraisal suggested that the media can be played by the learners with little revision. Snakes and ladders game is also considered effective and practical as an instructional learning medium in social studies lesson. Social studies is one of the compulsory subjects in elementary education. Indonesian Government regulation No. 22 year 2006 on content standards clearly defines the objectives of social studies subjects at elementary/ junior secondary education levels as: to recognize concepts related to the life of the community and its environment, to have basic skill for logical and critical thinking, curiosity, inquiry, problem solving and skills in social life, to have commitment and awareness of social and human values, to communicate, cooperate and compete in plural society, local, national and global level (Yulianto Nugroho et al., 2019). The concepts about life of the community and its environment particularly about Hindu and Budhist history such as characters, kingdoms, and relics are somewhat abstract concepts for students, thus ilustrating the materials on the snakes and ladders board supported with questions cards can be of interest for young learner with their concrete to abstract way of thinking. 
With the use of this learning media, teachers can promote more active learning eventhough they are teaching a content-rich subject like social studies. This is in line with the study of board game approaches to knowledge acquisition which found that "teachers and learners confirmed the board game's effect of raising learning motivation and fun in the context of a theory-loaded content" (Taspinar et al., 2016, p. 115). In learning, students' participations are very necessary because without their involvement, learning might not be meaningful. Yulianto Nugroho et al. (2019) observed that Indonesian teachers tend to use lecture and question-and-answer method in teaching historical relics of Hindu and Buddhist kingdoms. The high level of student participation when the teacher used snakes and ladders learning media means that students were active in participating in social studies learning with the use of this learning media.

\section{Conclusion and Suggestion}

\section{Conclusion}

Based on the results and discussion, it can be concluded that development of snakes and ladders learning media for social studies in the materials of Hindu and Buddhist figures, kingdoms, and relics can be valid and practical, and effectively improves fifth grade primary school students' interest and learning outcomes. The snakes and ladders learning media is considered valid based on the experts' validation with average 4.3 (good). The effectiveness of this learning media meets the effectiveness criteria: (1) student participation in the learning process is high and (2) student learning outcomes meet the minimum learning mastery standard average at 79.04 of the ideal score of 100 and the completeness test of learning outcomes with the probability value of one sample t-test of $0.00<0.05$. The practicality of learning media is shown through the observation result of the implementation of the media with an average of 4.4 (good), whereas the results of the student interest questionnaire show that of 25 students (92\%) responded that they were happy with the subject matter taught, $80 \%$ of students responded that they were happy with the learning.

\section{Suggestion}

Based on the conclusions obtained, it is suggested that further research is needed in the form of verification and modification so that the use of snakes and ladders learning media is more optimal. Other subjects besides social studies are also recommended to be taught because the implementation of snakes and ladders learning media can be positively related with the increase in student participation, learning outcomes, and interest.

\section{Declaration of Conflicting Interests}

The authors declared no potential conflicts of interest with respect to the research, authorship, and/or publication of this article. 


\section{Funding}

The authors received no financial support for the research, authorship, and/or publication of this article.

\section{References}

Astuti, K. S., McPherson, G. G., Sugeng, B., Kurniasari, N., Herawan, T., Drake, C., Ashadi, Retnowati, E., \& Pierewan, A. C. (2019). 21st Century Innovation in Music Education: Proceedings of the 1st International Conference of the Music Education Community (INTERCOME 2018), October 25-26, 2018, Yogyakarta, Indonesia. Routledge.

Geroimenko, V. (2019). Augmented Reality Games I: Understanding the Pokémon GO phenomenon. Springer.

Hicks, D., van Hover, S., Doolittle, P. E., \& VanFossen, P. (2012). Learning social studies: An evidence-based approach. In K. R. Harris, S. Graham, T. Urdan, A. G. Bus, S. Major, \& H. L. Swanson (Eds.), APA educational psychology handbook, Vol. 3: Application to learning and teaching (pp. 283-307). American Psychological Association. https://doi .org/10.1037/13275-012

Ibam, E., Adekunle, T., \& Agbonifo, O. (2018). A moral education learning system based on the snakes and ladders game. EAI Endorsed Transactions on E-Learning, 5(17), 155641. https://doi.org/10.4108/eai.25-9-2018.155641

Lindasari, E., Ansari, K., \& Marice, M. (2019). Interactive multimedia development in learning of film review text for 8th Grade Students in Senior High School (SMP) 1 Tanjungmorawa. Budapest International Research and Critics in Linguistics and Education (BirLE) Journal, 2(4), 355-362. https://doi.org/10.33258/birle.v2i4.522

Meriyati, Latifah, S., Hidayah, N., Shawmi, A. N., Amrullah, M. A., \& Fitriana, N. S. (2019). Snake and ladder game integrated with Asmaul-Husna: Development of learning media. Journal of Physics: Conference Series, 1155, Article 012024. https://doi.org/10.1088/1742$6596 / 1155 / 1 / 012024$

Nora, Y. (n.d). Learning of social studies in elementary school as a medium to strengthen multicultural education in the curriculum era 2013. SHS Web of Conferences, 42, Article 00094. https://doi.org/10.1051/shsconf/20184200094

Roure, C., Kermarrec, G., \& Pasco, D. (2019). Effects of situational interest dimensions on students' learning strategies in physical education. European Physical Education Review, 25(2), 327-340. https://doi.org/10.1177/1356336X17732964

Santoso, D., \& Albaniah, S. (2020). Development of an Electrical Engineering Module for the Expertise Program of Industrial Electronics Engineering. Journal of Physics: Conference Series, 1456, 012060. https://doi.org/10.1088/1742-6596/1456/1/012060

Srinivasan, K. (2019). Snake and ladder games in cognition development on students with learning difficulties. Indian Journal of Dental Advancements, 10(4), 160-170. https://doi .org/10.5866/2018.10.10160

Swarat, S., Ortony, A., \& Revelle, W. (2012). Activity matters: Understanding student interest in school science. Journal of Research in Science Teaching, 49(4), 515-537. https://doi .org/10.1002/tea.21010

Taspinar, B., Schmidt, W., \& Schuhbauer, H. (2016). Gamification in education: A board game approach to knowledge acquisition. Procedia Computer Science, 99, 101-116. https://doi .org/10.1016/j.procs.2016.09.104 
Uge, S. (2019). Development of social studies learning model based on local wisdom in improving students' knowledge and social attitude. International Journal of Instruction, 12(3), 375-388. https://doi.org/10.29333/iji.2019.12323a

Yulianto Nugroho, A., Hartono, \& Sudiyanto. (2019, July). Needs assessment analysis of social science learning in primary school [Conference session]. 1st International Conference on Life, Innovation, Change and Knowledge (ICLICK 2018), Bandung, Indonesia. https://doi .org/10.2991/iclick-18.2019.55

\section{Author Biographies}

Ahmad Syawaluddin is a senior lecturer in Primary School Teacher Education, Faculty of Education, Universitas Negeri Makassar, Indonesia.

Contact: unmsyawal@unm.ac.id

Sidrah Afriani Rachman is a lecturer in Primary School Teacher Education, Faculty of Education, Universitas Negeri Makassar, Indonesia.

Contact: sidrah.afriani@unm.ac.id

Khaerunnisa is a lecturer in Primary School Teacher Education, Faculty of Education, Universitas Negeri Makassar, Indonesia.

Contact: khaerunnisa1495@gmail.com 